\title{
Az európai és a magyarországi kanyaróhelyzet összefoglalása és tanulságai
}

\author{
Lengyel György dr. ${ }^{1}$ - Ánosi Noel ${ }^{1}$ - Marossy Anna dr. ${ }^{1}$ \\ Mátyus Mária dr. ${ }^{1}$ - Bosnyákovits Tünde dr. $^{2}$ - Orosz László dr. ${ }^{2}$ \\ ${ }^{1}$ Magyar Honvédség Egészségügyi Központ, Védelem Egészségügyi Igazgatóság, Budapest \\ ${ }^{2}$ Csongrád Megyei Kormányhivatal, Népegészségügyi és Élelmiszerlánc-biztonsági Főosztály, Szeged
}

\begin{abstract}
A kanyaró az egyik legsúlyosabb megelőzhető fertőző megbetegedés, mely hazánkban az elmúlt 10-20 évben a ritkábban előforduló kórképek közé tartozott. Ennek egyik oka, hogy az 1969 után született magyar lakosság átoltottsága közel 99\%-os. A másik ok pedig az, hogy az oltási érát megelőző időszakban a gyakran előforduló országos kanyarójárványok az érintettekben életre szóló immunitást hagytak maguk után. A természetes és a mesterséges immunizáció így összességében tehát kiterjedt nyájimmunitást biztosított a populációnak. Az Európában jelenleg is zajló kanyarójárványok azonban rávilágítottak arra, hogy a megbetegedéssel kapcsolatos tünettani és differenciáldiagnosztikai ismeretek az utóbbi 20 évben háttérbe szorultak. Az európai kanyarójárványok hazánkra vonatkozó konzekvenciájának áttekintése mellett a jelen közlemény célja a kanyaró járványügyi kontrolljához szükséges klinikai és labordiagnosztikai ismeretek felelevenítése és összefoglalása.
\end{abstract}

Orv Hetil. 2019; 160(20): 767-773.

Kulcsszavak: kanyaró, Európa, nyájimmunitás, vakcináció, labordiagnosztika

\section{Summary and lessons of the European and Hungarian measles situation}

Measles is one of the most serious preventable infectious diseases, which in our country were among the rare diseases in the last 10 to 20 years. One of the reasons for this is that the Hungarian population born after 1969 was vaccinated in almost 99 percent. The other reason is that in the period prior to vaccination era, the often-occurring measles epidemics left life-long immunity in the affected persons. Thus, natural and artificial immunizations provided extensive herd immunity. However, the ongoing measles epidemics in Europe have highlighted the fact that the symptoms and differential diagnosis related to measles have been relegated to the negligible category for the last 20 years. In addition to reviewing the consequences of the European measles pandemics in Hungary, the purpose of this paper is to revise and summarize the clinical and laboratory knowledge required to establish a definitive epidemiological control of measles.

Keywords: measles, Europe, herd immunity, vaccination, laboratory diagnosis

Lengyel Gy, Ánosi N, Marossy A, Mátyus M, Bosnyákovits T, Orosz L. [Summary and lessons of the European and Hungarian measles situation]. Orv Hetil. 2019; 160(20): 767-773.

(Beérkezett: 2018. december 20.; elfogadva: 2019. január 14.)

A Szerkesztőség felkérésére készült tanulmány.

\section{Rövidítések}

$\mathrm{ECDC}=($ European Centre for Disease Prevention and Control) Európai Betegségmegelőzési és Járványvédelmi Központ; $\mathrm{EEG}=$ elektroencefalográfia $;$ ELISA = (enzyme-linked immu- nosorbent assay) enzimhez kötött immunadszorbciós vizsgálat; EU = (European Union) Európai Unió; F = a kanyaróvírus fúziós glikoproteinje; $\mathrm{H}$ = a kanyaróvírus hemagglutinin fehérjéje; $\mathrm{IgG}=\mathrm{G}$-nehézlánc-osztályú immunglobulin; $\mathrm{IgM}=\mathrm{M}$ - 
nehézlánc-osztályú immunglobulin; L = a kanyaróvírus óriás polimerázfehérjéje; $M=$ a kanyaróvírus mátrixproteinje; $M M R-$ oltás $=$ mumpsz-morbilli-rubeola elleni védőoltás; $\mathrm{N}=$ a kanyaróvírus nukleokapszid proteinje; $\mathrm{P}=$ a kanyaróvírus foszfoproteinje; $\mathrm{PRNT}=$ (plaque reduction neutralization test) plakkredukciót mérố vírusneutralizációs teszt; $R_{0}$-érték $=\mathrm{az}$ alap reprodukciós ráta értéke; RNS = ribonukleinsav; spp. $=$ (species) fajok; SSPE = (subacute sclerosing panencephalitis) szubakut szklerotizáló panencephalitis; $\mathrm{WHO}=($ World Health Organization) Egészségügyi Világszervezet

A kanyaró vírusa a Paramyxoviridae családba tartozó, negatív egyszálú RNS-genommal rendelkező, kizárólagosan emberi kórokozó. A virion szabálytalan alakú, pleomorf, nagysága 100-700 nm között váltakozik [1]. Örökítőanyaga nem szegmentált, antigénszerkezete jelentősen nem változik. A kanyaró cseppfertőzéssel terjedő jellegzetes, maculopapulosus kiütésekkel járó, elsősorban gyermekkori betegség, de megfelelő védettség hiányában bármely életkorban képes megbetegedést okozni [2]. Az alap reprodukciós szám (az ún. $R_{0}$-érték, mely azt adja meg, hogy egy fertőzött egyed védettség nélküli populációban várhatóan hány másodlagos esetet okoz) a kanyaró esetében 15 körüli [3]. Ez alapján az egyik legragályosabb emberi betegségról beszélhetünk, melynek lappangási ideje 7-13 nap. A fertőződést követően a vírus először a légutak hámsejtjeiben replikálódik, majd a regionális nyirokcsomókban elszaporodva az elsődleges viraemia juttatja a lymphoid rendszer sejtjeibe. Innen, a további szaporodást követően kialakuló másodlagos viraemia révén jön létre a generalizált fertőzés $[1,4]$.

A klinikai tünetek jellemzően a lappangási idő 10. napján kezdődnek, magas lázzal, köhögéssel, náthaszerü állapottal, conjunctivitisszel, valamint jellemző lehet a photophobia is $[1,5]$. Általában a tünetek kezdetét követő második napon megjelennek az ún. Koplik-foltok, melyek a buccalis nyálkahártyán látható apró, fehéres felrakódások [5]. A Koplik-foltok megjelenését követően 12-24 óra múlva feltünnek a kiütések a vírus ellen kialakuló immunválasz következményeként, amelyek jellemzően a fül mögött, a hajas fejbőr határán, az arcon és felülről lefelé haladva a törzs, valamint a végtagok irányába terjednek $[5,6]$. A morbilliform kiütés jellemzően erythemás alapon elhelyezkedő macula, mely idővel konfluál, reticularis megjelenést ölt, majd az exanthemák a megjelenésük sorrendjében, finom hámlás kíséretében eltűnnek [5]. A betegek többsége 7-10 napon belül felépül, kivéve a szövődményes eseteket.

\section{A kanyaró lehetséges szövődményei és diagnózisuk}

A kanyarófertőzés egyik legsúlyosabb lehetséges szövődménye az encephalitis, amely kialakulhat a fertőzést követő 2-30 nap között bármikor [7]. Az idegrendszeri tünetek kialakulását követően a gerincvelői folyadékból, molekuláris biológiai módszerekkel kimutatható a kórokozó. Ebben a stádiumban azonban az intrathecalis ellenanyag kimutatása még nem tekinthető adekvát vizsgálatnak [8]. Diagnosztikus értékü lehet a gyulladás következményeként a liquorban tapasztalható emelkedett fehérjeszint és lymphocytaszám [9]. Akár egy évvel a fertőzést követően is kialakulhat az idegrendszeri érintettség egy speciális formája, az úgynevezett measles inclusion-body encephalitis immunszuppresszált gyermekek esetében. A klinikai képet ez esetben többnyire a lázmentes görcsrohamok uralják [10]. Az idegrendszeri szövődmények közül a legrettegettebb, azonban egyben a legritkább típus a szubakut szklerotizáló panencephalitis (SSPE). Általában azokat érinti, akik 2 éves koruk előtt fertőződtek meg, és akikben a primer infekció reziduálisan szaporodó virionokat hagyott hátra a központi idegrendszerben. Az első tünetek töbnyire 10-15 éves korban jelennek meg, gyakran csak enyhébb, nemspecifikus panaszok formájában (például figyelemhiányos hiperaktivitási zavar, tanulási nehézségek). Az első tünetek megjelenésétől számított 1-3 éven belül a neurológiai tünetek a kómáig súlyosbodhatnak [10]. Az SSPE differenciáldiagnosztikájában fontos laboratóriumi marker az intrathecalis ellenanyag termelésének kimutatása [11]. Az SSPE diagnózisa gyakran nehézségekbe ütközik, mivel a kiváltó ok és a tünetek között több mint tíz év is eltelhet, továbbá számos egyéb gyermekkori neurológiai kórképtől szükséges elkülöníteni (például metakromáziás leukodystrophia, Krabbe-kór, mitokondriális encephalopathia, X-kromoszómához kötött adrenoleukodystrophia, virális encephalitisek, valamint a központi idegrendszert érintő tárolási betegségek). Az SSPE diagnózisának felállítását támogatja a periodicitást mutató EEG-aktivitás (ún. Radermecker-komplex), továbbá a szimmetrikus, bilaterális fehérállomány-abnormalitások, valamint a diffúz atrophia megjelenése az agyállományban [11].

A kanyarófertőzés leggyakoribb szövődményei a légutakat érintik, mivel az erodált nyálkahártyán megtelepedő baktériumok, valamint a vírus indukálta immunszuppresszió következtében kialakuló bakteriális felülfertőződés súlyosbítja a tüneteket. A leggyakoribb kórokozók a Streptococcus spp., valamint a Klebsiella pneumoniae [12]. A légúti eredetú szövődmények közé tartozik még a vírusos középfülgyulladás, a vírusos pneumonitis és a laryngotracheobronchitis. A tüdőgyulladás igen súlyos is lehet, a végzetes kanyarófertőzések nagy részében a pneumonia válik letálissá [13].

Kanyaróvírus-fertőzéssel összefüggésben a gastrointestinalis szövődmények sem számítanak ritkának. A hasmenés, enteritis mellett akár vakbélgyulladás is előfordulhat. Fiatal felnőttekben a máj lehetséges érintettségét is igazolták. Egy francia tanulmány megemlíti, hogy a kanyaróval fertőzött felnőtt páciensek $81 \%$-ánál mutattak ki emelkedett májenzimértékeket, több mint 10\%-uknál pedig ez az emelkedés a normálérték több mint tíz- 
szerese volt [14]. Megjegyzendő, hogy ez utóbbi eltérést a 2017. évi, makói kanyarójárvány kapcsán is megfigyelték a szerzők (nem publikált adat).

A szemészeti szövődmények kialakulásának veszélye sem elhanyagolható. Bár a fertőzés következtében szinte mindig kialakul conjunctivitis, kialakulhat továbbá keratitis, corneafekély vagy a szem hátsó szegmentumában retinitis, illetve uveitis [15]. A fejlődő országokban a gyermekkori vakság egyik jelentős oka a kanyaró, különösen, ha A-vitamin-hiánnyal párosul [16].

A betegek egy részében akut veseelégtelenség is kialakul a fertőzés következtében, ezért érdemes a kanyarós betegek retenciós paramétereit rendszeresen ellenőrizni [17].

\section{Differenciáldiagnosztika}

Számos felnőttkori betegség, valamint gyógyszerhatás utánozhat morbilliform exanthemákat. Az erythemás, vesiculosus kiütések elsősorban virális eredetre utalnak, míg a gyógyszer által kiváltott exanthemák általában pustulosus, papulosus jellegüek [18].

Az adenovírusfertőzés ritkán - elsősorban immunszuppresszált betegeknél - szintén okozhat diffúz morbilliform és hólyagos kiütéseket [5]. Az etiológia tisztázásához molekuláris virológiai módszerekre van szükség.

A mononucleosisszindrómát okozó Epstein-Barr-vírus, valamint a cytomegalovirus is utánozhatja a kanyaróban látott bőrelváltozásokat. Ezek az exanthemák együtt járhatnak petechiákkal és urticariával, továbbá gyakorta akkor jelentkeznek, amikor a vírusfertőzés tüneteit bizonyos béta-laktám típusú antibiotikumokkal kezelik (ún. „amoxicillin rash”) [5]. Az emelkedett szérummájenzim-érték nem diagnosztikus értékü, mivel ilyet a kanyarófertőzés esetén is megfigyeltek [14].

A humán herpeszvírus-6- és -7-fertőzés is képes morbilliform kiütéseket létrehozni, akár petechiákkal. Elsősorban szervtranszplantációt követően jelentkező tünetek esetén kell ezekre a kórokozókra gondolni [19].

A parvovírus-B19-fertózésben a kiütések mellett jelentkezhet ízületi fájdalom, ízületi gyulladás és myalgia. Ezek a tünetek szintén megnehezítik a kanyarótól való elkülönítést. Jellegzetes az arcon megjelenő indurált pillangóerythema (slapped cheek - „felpofozott arc”), ezt követően maculopapularis eruptiók jelenhetnek meg a törzsön. A fertőzés korai tünetei esetén molekuláris diagnosztika, a fertőzés második stádiumában pedig szerológia segítheti a differenciáldiagnosztikát [20].

$\mathrm{Ha}$ az anamnézisben időben közeli mediterrán vagy trópusi területre történt utazás szerepel, akkor az egzotikus vírusfertőzésekre is számítani kell. Ezek között megemlíthető a dengue-, a Zika- vagy a chikungunyavírus. Mindhárom fertőzés morbilliform kiütésekkel, lázzal és ízületi fájdalommal jár. Chikungunyafertőzés esetén előfordulhat továbbá fejfájás, fényérzékenység és csont- vagy ízületi fájdalom is. A kiütések megjelenésekor a molekuláris diagnosztika segítheti a kóroki tényező azonosítását [21].

\section{A kanyaró megelőzése}

Mivel nincs lehetőség specifikus antivirális kezelésre, a primer prevenció szerepe különösen fontos. Ennek megvalósítására Magyarországon 1969 óta kötelezően kapnak életkorhoz kötött védőoltást a gyermekek [6]. Az 1969 előtt születettek túlnyomó többsége - az akkoriban zajló kiterjedt és rendszeres járványok következtében - természetes védettséggel rendelkezik [6]. 1989-ig egy oltás volt kötelező a gyermekek számára, azonban az időnként fellángoló járványok miatt egyes korosztályok kampányok keretében emlékeztető oltásban is részesültek [6]. 1989 óta 15 hónapos korban, majd 11 éves korban kapnak kombinált mumpsz-morbilli-rubeola elleni (MMR-) oltást a gyermekek [6]. Hazánkban az érintett korosztályok átoltottsága 98\%-os [6]. Az oltás nyújtotta védettség azonban nem életre szóló, az idő múlásával az immunitás gyengül [5]. A kialvó immunitás miatti megbetegedés oka lehet ez az ún. másodlagos oltási elégtelenség (szemben az oltás ellenére egyáltalán ki nem alakuló immunitás esetével, mely az elsődleges oltási elégtelenség) [22]. Összességében azonban megállapítható, hogy a kanyaró az egyik legsúlyosabb, vakcinálással igen jól megelőzhető fertőző megbetegedés. Az oltás hatékonyságának és a már meglévő immunitásnak az ellenőrzésére alkalmazhatók a kanyaróellenes ellenanyagok mennyiségi meghatározását célzó kvantitatív ELISA- és vírusneutralizációs vizsgálati módszerek.

\section{Az immunstatus megállapításának laboratóriumi háttere}

Már a fertőzés korai szakaszában, a kiütések megjelenésével egy időben mindegyik virális fehérjével szemben megindul a jól detektálható ellenanyag-termelés. Így megfelelő tesztek birtokában - detektálhatók a nukleokapszid $(\mathrm{N})$, foszfoprotein $(\mathrm{P})$, óriás polimerázfehérje $(\mathrm{L})$, mátrixprotein $(\mathrm{M})$, hemagglutinin $(\mathrm{H})$ és fúziós glikoprotein (F) elleni antitestek is. Kezdetben $\operatorname{IgM}$, majd az osztályváltást követően alacsony aviditású IgG szekretálódik. Az anti-N-ellenanyag gyorsan és nagy mennyiségben keletkezik, ennek hiánya egyértelmúen jelzi a szeronegativitást. A vírusneutralizációért a H- és F-glikoproteinekkel szemben termelődött ellenanyagok felelősek. A kiütések megjelenésének pillanatában a neutralizációs ellenanyagok relatív mennyisége az összes ellenanyag mennyiségéhez képest csekély. Mintegy 14 nappal a kiütések megjelenését követően az összes ellenanyag relatív mennyiségének körülbelül harmadát teszik ki a vírust hatékonyan neutralizáló ellenanyagok [23].

A természetes úton átvészelt fertőzés során létrejövő antitesttiter még évtizedekkel a fertőzést követően is nagyságrendekkel magasabb, mint az oltás által létrehozott immunválasz [24]. A mesterséges immunizálás során kialakult memóriasejtek által termelt alacsonyabb titer gyakran az ELISA-módszer detektálási határán mozog [25]. A memóriasejtek és a celluláris immunvá- 
lasz jelenlétével is számolva nem is olyan könnyű definiálni az immunitáshoz elégséges antitest-koncentrációt.

Az ELISA-módszeren alapuló tesztek kumulatív IgGszintet mérnek, ezzel szemben a plakkredukciót mérő vírusneutralizációs teszt (PRNT) kizárólag a neutralizáló ellenanyag szintjéről ad tájékoztatást (tulajdonképpen a vírus $\mathrm{H}$-fehérjéje ellen termelődött antitestek kimutatására alkalmas). A PRNT kellően szenzitív, és a mért neutralizálóantitest-titer jól korrelál a fertőzéssel szembeni immunitással. A módszer azonban időigényes (5-7 nap), nehezen standardizálható, és így nem alkalmas a rutinszürővizsgálatok kivitelezésére [26]. Cohen és mtsai kidolgoztak egy könnyen beállítható PRNT-protokollt, melyet az ELISA-val való kanyarószűrés kiegészítésére ajánlanak (negatív savók újramérése PRNT-vel) [27]. A PRNT-módszerrel mért titereredmények összevethetők az ELISA-módszerrel kapott eredményekkel. Mancuso és mtsai megállapították, hogy az ELISA-módszerrel egyébként negatívnak mutatkozó minták 87,5\%-ban mutattak vírusneutralizációt, ami azt sugallja, hogy az ELISA-módszer felülbecsüli a ténylegesen negatív és ezáltal a fogékony személyek számát [28]. Az irodalomban elérhető adatok alapján a 150-200 mIU/ml kanyaróellenes IgG-koncentráció már elegendő a vírusneutralizációhoz és a megfelelő védettség biztosításához. PRNTvizsgálat esetén viszont már a 1 : 120 titer is bizonyosan védettséget jelent [29]. Mindezek alapján elmondható, hogy a jelenleg alkalmazott, az összes kanyaróvírus elleni ellenanyag koncentrációját mérő protokollok nem adnak pontos információt a valóban effektív, neutralizáló ellenanyagok szintjéról, viszont jól alkalmazhatók szürésre, és a pozitív eredmény egyértelmúen igazolja a kanyaróvírussal szembeni ellenanyagok jelenlétét.

\section{Az aktuális európai járványügyi helyzet áttekintése}

Az Egészségügyi Világszervezet (WHO) európai kanyarójelentése szerint 2018 első félévében igen jelentős számú megbetegedést regisztráltak a kontinensen [30]. Több mint 41000 gyermek és felnőtt esetében igazolták a fertőzést 6 hónap leforgása alatt, ami jóval meghaladja még az éves esetszámokat is. A regisztrált megbetegedések közül 37 fatális kimenetellel végződött [30]. Az esetek több mint felét Ukrajnában észlelték (23000 eset), de jelentős számú megbetegedést jelentett Franciaország, Grúzia, Görögország, Olaszország, Oroszország és Szerbia is [30]. Mindegyik említett ország jelzett haláleseteket is, a legtöbbet Szerbia [30].

$\mathrm{Az}$ Európai Betegségmegelőzési és Járványvédelmi Központ (ECDC) honlapján közzétett adatok alapján a 2017. július 1. és 2018. június 30. közötti egyéves időszakban az Európai Unió (EU) tagországaiból összesen 13234 esetet jelentettek. Az összes tagországban előfordultak megbetegedések, kizárólag Málta nem jelentett egyet sem [31]. A bejelentett esetszámmal kapcsolatban azonban maga az ECDC is megjegyzi, hogy valószínü-

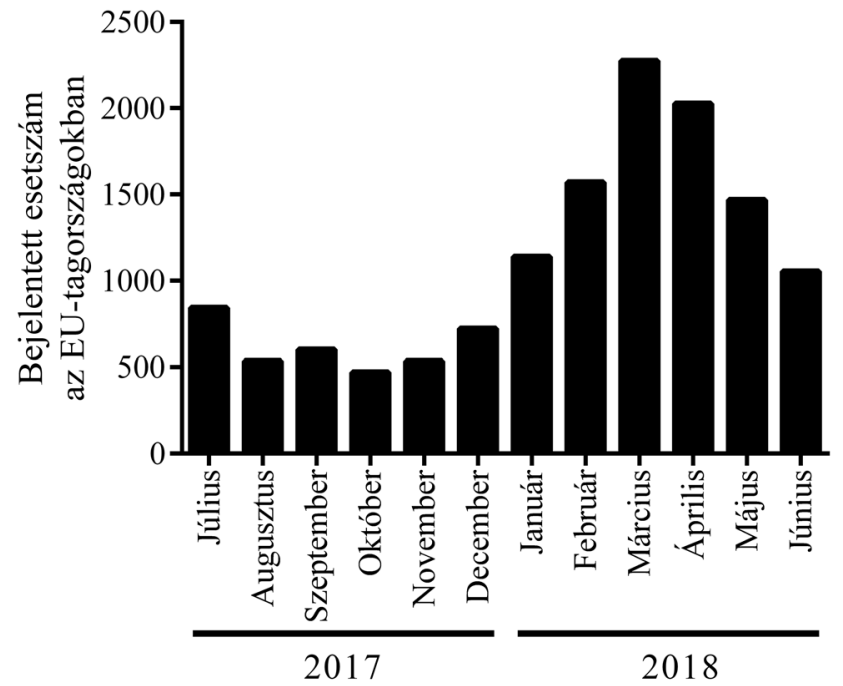

1. ábra

A kanyarós esetek száma 2017 júliusa és 2018 júniusa között az Európai Unió tagországaiban összesen (az adatok forrása: https://ecdc.europa.eu/en/publications-data/number-measles-cases-month-and-notification-rate-million-populationcountry-0)

leg alulbecsült, mivel egyes országokban nem történik meg a teljes körú és részletes járványügyi kivizsgálás. A legtöbb esetet az EU országai közül ebben az időszakban Olaszország (3341), Görögország (3193), Franciaország (2740) és Románia (1354) jelentette. Ezek rendre az összes megbetegedés $25,24,21$ és 10 százalékát képviselték [31]. Az adatokat ábrázoló diagramon jól látható, hogy 2018 első félévében az esetszámok jelentősen emelkedtek az előző év második félévéhez képest (1. ábra). A megbetegedések 69\%-át sikerült laboratóriumi vizsgálatokkal is igazolni. Az esetek eloszlását az ECDC 2018. évi adatai alapján országonként ábrázolva felismerhető, hogy az EU tagországai közül jelenleg Franciaországban, Hollandiában és Lengyelországban a legsúlyosabb a helyzet (2. ábra).

Az ECDC összesített adatai szerint a legtöbb esetet (763) március hónapban, Franciaországban regisztrálták [31]. A kormegoszlást illetően az esetek 30\%-a 5 éven aluli kisgyermek, 51\% pedig 15 évesnél idősebb volt. Megjegyzendő, hogy az ECDC összesítése szerint az előfordulások 68\%-a endémiás terjedés következményének tekinthető, ami az oltási rendszer alkalmazásának súlyos elégtelenségére hívja fel a figyelmet [31].

\section{A 2017. évi magyarországi esetek tanulságai}

Magyarországon 2013 és 2017 között összesen 37 esetet regisztráltak, ennek 97\%-a 2017-ben fordult elö [32]. A fertőzések valószínű forrása lehetett a romániai, illetve az EU egyéb országaiban tapasztalható kanyarójárványokból származó behurcolás [3]. Az első eseteket hazánkban 2017 márciusában jelentették a makói kórház személyzetének köréből. A járványügyi kivizsgálás során 


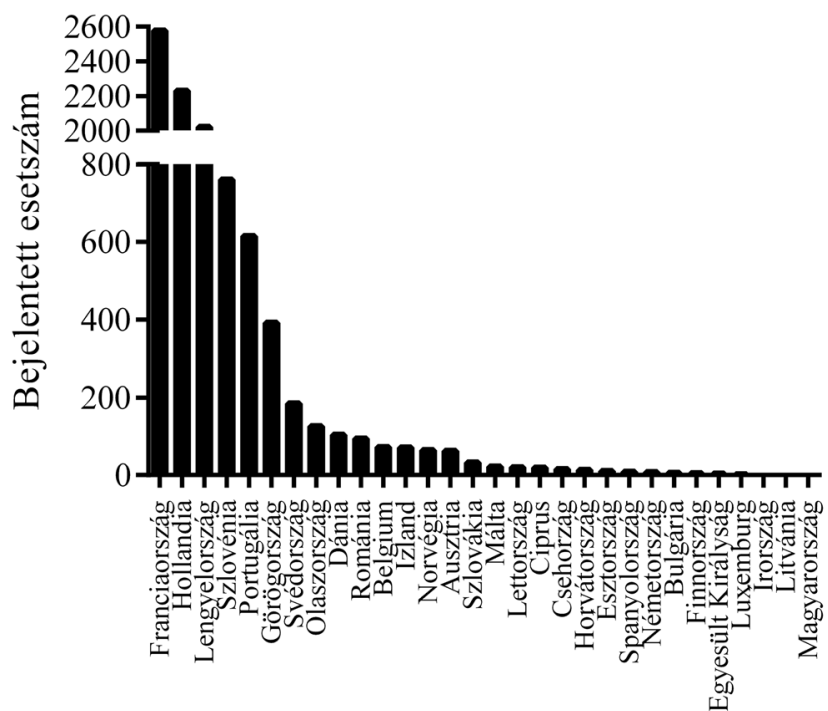

2. ábra

A kanyarós esetek száma 2018 januárja és júniusa között az Európai Unió tagországaiban országonként (az adatok forrása https://ecdc.europa.eu/en/publications-data/number-meas les-cases-month-and-notification-rate-million-populationcountry-0)

bizonyítást nyert, hogy egy romániai beteg hurcolta be a vírust az intézménybe (3. ábra). Ezt követően terjedt a vírus a Sürgősségi Betegellátó Osztály dolgozói között, akik még egy harmadik fertőzési hullámot is elindítottak ugyan, de a hatékony járványügyi intézkedéseknek és feltételezhetően a kiterjedt vakcinálásnak köszönhetően az infekció ezt követően már nem terjedt tovább (3. ábra). A második sporadikus járvány 2017 júliusában, Nyíregyházán, 6 oltatlan román gyermek általi behurcolás következtében tört ki. Több magyar egészségügyi dolgozó is

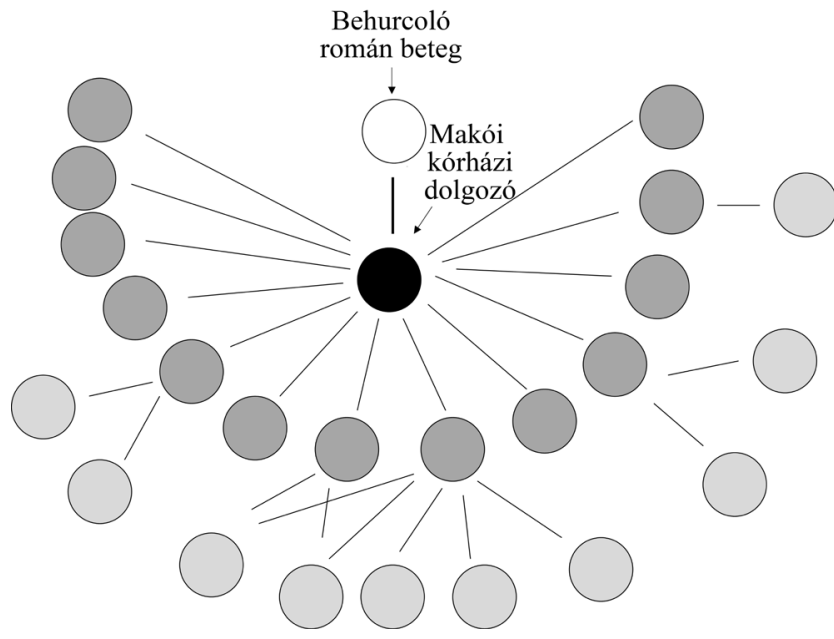

3. ábra

A kanyaró terjedése a makói kórház dolgozói és kontaktjaik között 2017 márciusában. A fertőzést behurcoló román beteg feltételezhetően a kórház sürgősségi osztályának egyik dolgozóját fertőzte meg először, aki továbbadta az infekciót kollégáinak. Ezután még egy harmadik fertőzési hullám is kialakult, de a járványügyi intézkedések hatására ezzel a járvány megszűnt. Meg jegyzendő, hogy az utolsó hullámban már sokkal kevesebb megbetegedést regisztráltak (a folyamatos vonalak az érintett személyek közötti, felderített kapcsolatokat jelölik) megfertőződött, ezt laboratóriumi vizsgálatok is igazolták. A harmadik esethalmozódás Bács-Kiskun megyében történt, szintén oltatlan, román gyermekek között ütötte fel a fejét a megbetegedés. Ez esetben magyar állampolgárok nem voltak érintettek [3].

Mindegyik esetben a gyors és hatékony járványügyi intézkedések (aktív surveillance, karantén, izoláció, kontaktazonosítás, megfigyelés és posztexpozíciós vakcináció) révén a megbetegedések további terjedését sikerült megelőzni [3]. Fontos azonban megjegyezni, hogy a magyar lakosság körében történt terjedés - bármilyen minimális volt is - felhívja a figyelmet az immunizáltság hiányosságaira.

\section{Immunizációs rés lehetősége a populációban}

Egy friss magyar tanulmány, mely több mint 2000 egészségügyi dolgozó kanyaró elleni védettségét mérte fel, megállapította, hogy a 41-45 éves korosztályban a védettek aránya csak 86,2\% [33]. Ezt az eredményt egy másik, szintén 2018. évi, mintegy 1985 szérumot vizsgáló magyar tanulmány is megerősíti, melynek szerzői az 1969 és 1977 között, valamint az 1978 és 1987 között született korosztályokban tapasztaltak gyengült immunitást a populáció többi részéhez képest [34]. Ennek okaként a szerzők az elsődleges oltási elégtelenséget, vakcinakezelési problémákat és a nem megfelelő oltási életkort nevezik meg [34]. A két közlemény hasonló korosztályokat jelöl meg, mint amelyeket az említett, 2017. évi magyarországi sporadikus járványokban érintett egészségügyi dolgozók reprezentáltak [3].

Hasonló megfigyelések azonban Európa más országaiban is születtek. Egy 2013-as, 2018-ban publikált felmérés eredményei szerint Szlovákiában a 35-44 éves korosztályban mértek 80,4\%-os védettséget [35]. Ezt megerősíti egy 2017. évi közlemény is, melynek szerzői a 30-45 éves korosztályban tapasztaltak gyengült immunitást Szlovákiában [36]. Csehországban szintén a 3050 éves korosztályban mértek alacsony ellenanyagtitert egy 2017. évi tanulmány szerint [37]. A szerzők itt már egyértelmúen felhívják a figyelmet az évtizedekkel az oltás után kritikusan gyengülő immunitás lehetőségére.

A fenti adatokból kiindulva elképzelhető az egyes korosztályokat érintő másodlagos oltási elégtelenség előfordulása a magyar populációban is. Mivel az $R_{0}$-érték alapján a populáció kanyarómentességéhez legalább 95\%-os védettség szükséges [3], az ilyen széles korosztályokat felölelő immunizációs rések a betegség újbóli megjelenését idézhetik elő, ezért az okok kivizsgálása nélkülözhetetlennek tünik a további eredményes védekezéshez. Erre pedig a nemzetközi szakirodalom alapján is csak a megfelelő minőségben és gyakorisággal elvégzett, populációs szinten is reprezentatív szerológiai felmérések alkalmasak $[38,39]$. 
Anyagi támogatás: A közlemény megírása, illetve a kapcsolódó kutatómunka anyagi támogatásban nem részesült.

Szerzői munkamegosztás: L. Gy.: A kézirattervezet elkészítése, irodalomkeresés. Á. N.: Irodalmazás, a kézirattervezet átnézése. M. A., M. M.: Irodalmazás, a kézirat átnézése. B. T.: A kézirat átnézése. O. L.: A kézirattervezet elkészítése, a kézirat véglegesítése. A cikk végleges változatát valamennyi szerző elolvasta és jóváhagyta.

Érdekeltségek: A kézirattal összefüggő érdekeltsége egyik szerzőnek sincs.

\section{Irodalom}

[1] Mándi Y. Paramyxoviruses. In: Pál T. (ed.) Textbook of medical microbiology. [Paramyxovírusok. In: Pál T. (szerk.) Az orvosi mikrobiológia tankönyve.] Medicina Könyvkiadó, Budapest, 2012; pp. 213-217. [Hungarian]

[2] Chen SS. Measles. In: Steele RW, et al. (eds.) Overview practice essentials. Available from: http://emedicine.medscape.com/ article/966220-overview [accessed: December 9, 2018].

[3] Orosz L, Gáspár G, Rózsa Á, et al. Epidemiological situation of measles in Romania, Italy, and Hungary: on what threats should we focus nowadays? Acta Microbiol Immunol Hung. 2018; 65: 127-134.

[4] Gershon A. Measles virus. In: Mandell GL, Bennett JE, Dolin R (eds.) Mandell, Douglas, and Bennett's principles and practice of infectious diseases. 7th edition. Churchill Livingstone Elsevier, London, 2010; pp. 2229-2236.

[5] Mészner Zs, Timár L. Morbilli. In: Szalka A, Timár L, Ludwig E, et al. (eds.) Infectology. [Morbilli. In: Szalka A, Timár L, Ludwig E, et al. (szerk.) Infektológia.] Medicina Könyvkiadó, Budapest, 2005; pp. 259-261. [Hungarian]

[6] Information from the National Centre for Epidemiology of Hungary on measles. [Az Országos Epidemiológiai Központ tájékoztatója a kanyaróról.] Állami Népegészségügyi és Tisztiorvosi Szolgálat, Budapest, 2017. 03. 13. Available from: https:// www.antsz.hu/felso_menu/temaink/jarvany/jarvany_archivum/kanyaro/tajekoztatokanyarorol.html [accessed: December $9,2018]$.

[7] Fisher DL, Defres S, Solomon T, et al. Measles-induced encephalitis. QJM 2015; 108: 177-182.

[8] Hosoya M. Measles encephalitis: direct viral invasion or autoimmune-mediated inflammation. Intern Med. 2006; 45: 841-842.

[9] Sonneville R, Klein IF, Wolff M, et al. Update on investigation and management of postinfectious encephalitis. Curr Opin Neurol. 2010; 23: 300-304.

[10] Cherry JD. Measles virus. In: Cherry JD. (ed.) Feigin and Cherry's textbook of pediatric infectious diseases. Elsevier Saunders, Philadelphia, PA, 2014; pp. 2373-2395.

[11] Honarmand S, Glaser CA, Chow E, et al. Subacute sclerosing panencephalitis in the differential diagnosis of encephalitis. Neurology 2004; 63: 1489-1493.

[12] Quiambao BP, Gatchalian SR, Halonen P, et al. Coinfection is common in measles-associated pneumonia. Pediatr Infect Dis J. 1998; 17: 89-93.

[13] Hussey GD, Clements CJ. Clinical problems in measles case management. Ann Trop Paediatr. 1996; 16: 307-317.

[14] Dinh A, Fleuret V, Hanslik T, et al. Liver involvement in adults with measles. Int J Infect Dis. 2013; 17: e1243-el244.

[15] Végh M, Hári-Kovács A, Roth HW, et al. Ophthalmological symptoms of measles and their treatment. [A kanyaró szemészet tünetei és kezelése.] Orv Hetil. 2017; 158: 1523-1527. [Hungarian]

[16] Foster A, Sommer A. Corneal ulceration, measles, and childhood blindness in Tanzania. Br J Ophthalmol. 1987; 71: 331-343.

[17] Chassort A, Coutherut J, Moreau-Klein A, et al. Renal dysfunction in adults during measles. Med Mal Infect. 2015; 45: 165168.

[18] Drago F, Paolino S, Rebora A, et al. The challenge of diagnosing atypical exanthems: a clinico-laboratory study. J Am Acad Dermatol. 2012; 67: 1282-1288.

[19] Razonable RR. Human herpesviruses 6, 7 and 8 in solid organ transplant recipients. Am J Transplant. 2013; 13 (Suppl 3): 6777.

[20] Mage V, Lipsker D, Barbarot S, et al. Different patterns of skin manifestations associated with parvovirus B19 primary infection in adults. J Am Acad Dermatol. 2014; 71: 62-69.

[21] Martinez JD, Garza JA, Cuellar-Barboza A. Going viral 2019: Zika, Chikungunya, and Dengue. Dermatol Clin. 2019; 37: 95-105.

[22] Holzmann H, Hengel H, Tenbusch M, et al. Eradication of measles: remaining challenges. Med Microbiol Immunol. 2016; 205 : 201-208.

[23] McFarlin DE, Bellini WJ, Mingioli ES, et al. Monospecific antibody to the haemagglutinin of measles virus. J Gen Virol. 1980; 48: 425-429.

[24] Kang HJ, Han YW, Kim SJ, et al. An increasing, potentially measles-susceptible population over time after vaccination in Korea. Vaccine 2017; 35: 4126-4132.

[25] Christenson B, Böttiger M. Measles antibody: comparison of long-term vaccination titres, early vaccination titres and naturally acquired immunity to and booster effects on the measles virus. Vaccine 1994; 12: 129-133.

[26] Cohen BJ, Doblas D, Andrews N, et al. Comparison of plaque reduction neutralisation test (PRNT) and measles virus-specific IgG ELISA for assessing immunogenicity of measles vaccination. Vaccine 2008; 26: 6392-6397.

[27] Cohen BJ, Audet S, Andrews N, et al. Plaque reduction neutralization test for measles antibodies: description of a standardised laboratory method for use in immunogenicity studies of aerosol vaccination. Vaccine 2007; 26: 59-66.

[28] Mancuso JD, Krauss MR, Audet S, et al. ELISA underestimates measles antibody seroprevalence in US military recruits. Vaccine 2008; 26: 4877-4878.

[29] Chen RT, Markowitz LE, Albrecht P, et al. Measles antibody: reevaluation of protective titers. J Infect Dis. 1990; 162: 10361042.

[30] Measles cases hit record high in the European Region. Available from: http://www.euro.who.int/en/media-centre/sections/ press-releases $/ 2018 /$ measles-cases-hit-record-high-in-the-european-region [accessed: December 9, 2018].

[31] European Centre for Disease Prevention and Control. Monthly measles and rubella monitoring report. Solna, August 2018. Available from: https://ecdc.europa.eu/en/publications-data/ monthly-measles-and-rubella-monitoring-report-august-2018 [accessed: December 9, 2018].

[32] Report on Communicable Diseases in Hungary between 2013 and 2017. [Bejelentett fertőző megbetegedések Magyarországon 2013-2017.] Available from: https://www.antsz.hu/ data/cms87738/Fertozo_2017.pdf [accessed: December 9, 2018].

[33] Lengyel G, Marossy A, Ánosi N, et al. Screening of more than 2000 Hungarian healthcare workers' anti-measles antibody level: results and possible population-level consequences. Epidemiol Infect. 2019; 147: E7. [Epub 2018 Sep 11]

[34] Böröcz K, Csizmadia Z, Markovics Á, et al. Development of a robust and standardized immunoserological assay for detection 
of anti-measles IgG antibodies in human sera. J Immunol Methods 2019 ; 464: $1-8$.

[35] Tomášková H, Zelená H, Kloudová A, et al. Serological survey of measles immunity in the Czech Republic, 2013. Cent Eur J Public Health 2018; 26: 22-27.

[36] Zibolenová J, Chladná Z, Švihrová V, et al. Estimation of the population susceptibility against measles in Slovakia. Cent Eur J Public Health 2017; 25: 46-54.

[37] Smetana J, Chlibek R, Hanovcova I, et al. Decreasing seroprevalence of measles antibodies after vaccination - possible gap in measles protection in adults in the Czech Republic. PLoS ONE 2017; 12: e0170257.
[38] Durrheim D. Measles elimination, immunity, serosurveys, and other immunity gap diagnostic tools. J Infect Dis. 2018; 218: 341-343

[39] Winter AK, Martinez ME, Cutts FT, et al. Benefits and challenges in using seroprevalence data to inform models for measles and rubella elimination. J Infect Dis. 2018; 218: 355-364.

(Orosz László dr., Szeged, Derkovits fasor 7-11., 6725 e-mail:drorosz@gmail.com)

\section{PÁLYÁZATI FELHÍVÁS}

\section{A MAGYAR PATHOLOGUSOK TÁRSASÁGA (MPT) és a MAGYAR ONKOLÓGUSOK TÁRSASÁGA ${ }^{\circledR}\left(\right.$ MOT $\left.^{\circledR}\right)$ - az Elnökség útján - tudományos tevékenység támogatása céljából meghirdeti a}

\section{9. évi „KROMPECHER ÖDÖN” pályázatot.}

A pályázat/pályamunka témája, címe: „Az emlörák modern szemlélete"

A pályamunka formája: tanulmány

A pályamunka díjazása: $150000 \mathrm{Ft}$

A pályázat feltételei, benyújtásának és elbírálásának módja

A pályázók köre

A pályázatra orvostanhallgatók és fogorvostan-hallgatók nyújthatnak be pályamunkát.

\section{A pályázat terjedelme}

A pályamunka - az irodalommal és a dokumentációval együtt - legfeljebb 80 oldal terjedelmü lehet.

\section{A pályamunka benyújtásának módja}

A pályamunkát jeligével kell benyújtani.

A szerző nevét és elérhetőségét (évfolyam, lakcím, telefonszám, e-mail cím) lezárt borítékban - melyen a jelige feltüntetésre kerül - kell mellékelni.

A pályamunkát bekötve kell benyújtani, a címlapon szerepeltetve a „KROMPECHER ÖDÖN PÁLYÁZAT” címet és az évszámot.

A pályamunka szerkezete a tudományos publikációk szerkezetével azonos.

A pályamunka beadási határideje: 2019. november 30.
A pályamunka benyújtásának helye:

Semmelweis Egyetem, II. sz. Pathologiai Intézet (Titkárság) 1091 Budapest, Üllői út 93.

Az értékelés szempontjai: a mű eredetisége, a mű stílusa, szerkezete, a felhasznált irodalom korszerüsége.

A pályázat elbírálásának módja:

A pályázat kiírói a bírálóbizottság tagjait az aktuális téma szakértői közül választják ki.

A pályázat elbírálásának határideje: 2020. január hó 10.

$\mathrm{Az}$ eredmény kihirdetése az elbírálási határidőt követően, a 2020. évi elsö Országos Metszetkonzultáción, 2020. január 31-én Krompecher Ödön leszármazottainak, valamint a kiíró Társaságok képviselőinek jelenlétében történik.

Az eredményt a kírók a meghirdetéssel azonos módon nyilvánosságra hozzák, továbbá arról a nyertest külön, az elbírálási határidő leteltét követő 15 napon belül írásban is értesítik

\section{Egyéb tájékoztatás}

A bírálóbizottság jogosult a legjobb díjazott pályamunkák szakdolgozatként történő elfogadására javaslatot tenni.

A közzététel (kiírás, eredményhirdetés) a Magyar Onkológia folyóiratban, a $\mathrm{MOT}^{\circledast}$ honlapján (www.oncology.hu) és az MPT honlapján (www.pathology.hu) történik.

Budapest, 2019. március 8.

az MPT részéről:

Dr. Sápi Zoltán

az MPT elnöke

a $\mathrm{MOT}^{\oplus}$ részéről
Dr. Zalatnai Attila

az MPT fötitkára
Dr. Arató Gabriella

az MPT pénztárosa
Dr. Mátrai Zoltán
a MOT elnöke
Dr. Nagy Péter

a MOT fötitkára
Dr. Vincze Borbála

a MOT kincstárnoka 